\title{
DEVELOPMENT OF TEMPE PROCESSING BUSSINESS THROUGH PRODUCT DIVERSIFICATION IN LENTENG AGUNG, SOUTH JAKARTA
}

\author{
Giyatmi Giyatmi $^{1 *}$, Iman Basriman ${ }^{1}$, Shanti Pujilestari ${ }^{1}$ \\ ${ }^{1}$ Study Program of Food Technology, Sahid University of Jakarta \\ *giyatmi@hotmail.com
}

\begin{abstract}
The purpose of this activity is to develop business activities for tempe producers as partners, located in Lenteng Agung, South Jakarta. The tempeproducer partners wanted that their tempe processing business to be more developed, with expectation that to improvetheir welfare. At the beginning, the partners only produced fresh tempe with a limited market due to many competitors producing the same product. Therefore, the partners were facing difficulties to increase their production volume. The outputs to be achieved in this activity for partners were (1) Diversification of processed tempe products and (2) business management. The stages of the activities carried out were (1) Introduction of tempe processing with regard to hygiene and sanitation principles; (2) Training of appropriate technology to diversify processed tempe products to provide added value and expand the market segment of tempe; and (3) Training of an economically productive community empowerment model in the form of business development management through the diversification of processed tempe products. To strengthen the efforts in business development, it is necessary to diversify products, namely semi-moist processed tempe products (tempe nuggets and temperolade) which can be consumed as side dishes. The processing process of processed tempe products used simple technology that can be done by small scale industries. In addition to the transfer of technology packages, the two partners were also trained the knowledge to assess the feasibility of the business.
\end{abstract}

Keywords : business feasibility, Lenteng Agung, product diversification, tempe nugget, tempe rolade

\section{INTRODUCTION}

The center of tempe and tofu production of Primkopti South Jakarta is located at Jl. Seratus Gg Sonton RT 03 RW 02 Lenteng Agung South Jakarta consisting of 18 tempe producer and 4 tofu producer (Figure 1). In general, tempe producers are micro entrepreneurs. This is inseparable from government policies that protect the tempe producer for small communities. The tempe producers who became partners said that they had started to become tempe producer since 1991, meaning that the work had been carried out for more than 25 years.

Tempe is a type of food source of vegetable protein that is widely consumed by the public. Tempe is generally made with makeshift conditions, impression of slums, and relatively no technological innovation in manufacturing and processing. In 2013, Primkopti South Jakarta received assistance from the importer of soybean, PT FKS Multiagro, for the restoration of the joint production kitchen building. Restoration of production infrastructure facilities in the form of repairs to production kitchen buildings and several types of equipment that support tempe production. Although it has been facilitated with adequate buildings and equipment, the partner has not been able to increase its production capacity. The average tempe production of each producer is $100 \mathrm{~kg}$ of soybeans per day. The tempe product is packed in plastic and leaves. 

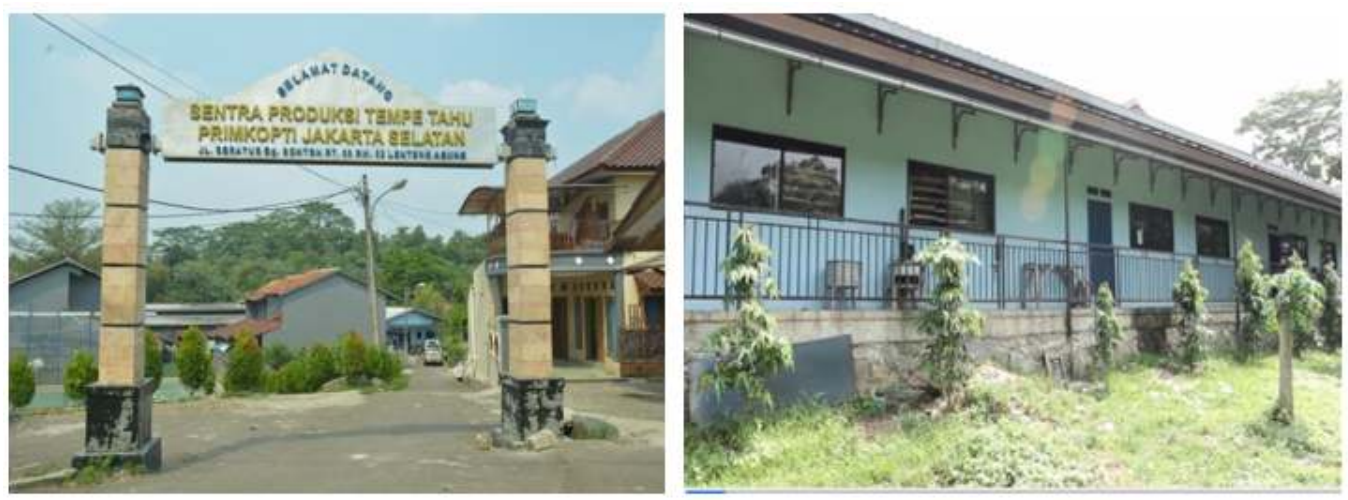

Figure 1. The production center of tempe and tofu at Lenteng Agung Primkopti South Jakarta

The process of making tempe uses traditional methods, namely boiling, soaking, stripping, giving mold yeast, wrapping and fermentation. In the production area that is used together, the equipment used is mostly already using good tools, such as cormorant and soaking containers made of stainless steel, soy peeler using mechanical equipment. The racks for fermentation also use materials from stainless steel (Figure 2).

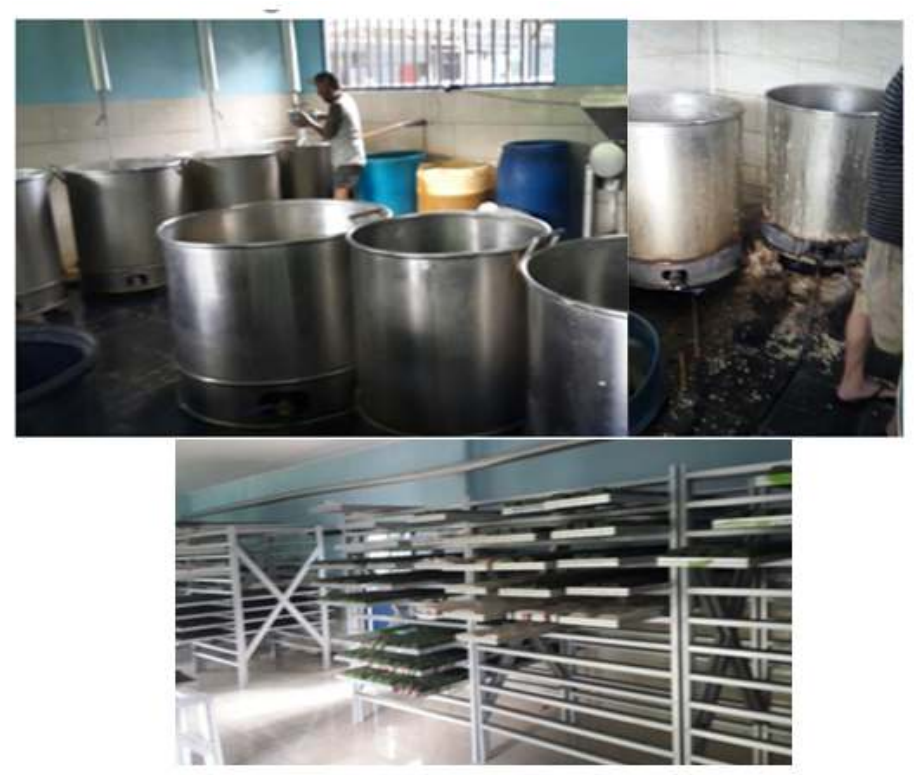

Figure 2. Tempe production equipment

The activity of partners run their business using very simple and traditional management. This is indeed a characteristic of micro businesses in general, business owners act directly as workers both in the aspects of production and marketing aspects. Employees act as helpers in all things needed and there is no specific division of labor. The number of working days is 30 days / month, meaning that this business does not have holidays. Employee working hours are also relatively no special arrangements. Both the owners and employees work according to routines, namely purchasing soybeans, boiling, soaking, stripping, giving yeast mold, wrapping and fermentation.

In conducting business, the partners do not make financial records. The profit and loss calculation for a business is carried out simply, namely revenue (the total price of the product produced) minus expenditure (the price of raw materials, mold yeast, packaging, and labor). Labor costs only calculate 
employee labor. The difference between revenue and expenditure with simple calculations is what is considered as profit, without taking into account the cost of labor yourself.

The problem faced by partners is that their business activities are limited business capacity and the products offered do not vary. For this reason, partners want business development, with the hope that their welfare will increase. To strengthen efforts in business development, new product development is needed, including tempe nugget and tempe rollader. The type of tempe processed products that will be tested on this activity is the initial product. If this business is successful, it can be developed into a variety of products that are more varied. The process of tempe production uses simple technology that can be done by small industries. However, the processing will be carried out in a hygienic manner and environment. Food safety and comfort to consume these products will be a top priority in production. For this reason, training / mentoring of processed tempe processing technology and adequate business management is needed.In marketing activities, the types of processed products to be tested will be packaged and labeled attractively. By prioritizing these things, consumers are expected to be more interested, which in turn is expected to increase tempe production volume.

\section{THEORETICAL FRAMEWORK}

In the literature study it was found that tempe was found in Centini fiber manuscript Volume 3 in 1875, which stated that the word tempe had been found, which showed that this traditional food had been known for centuries, especially in the Javanese culture of eating. Furthermore, tempe production spread throughout Indonesia, in line with the spread of Javanese people migrating to all corners of the country (Astawan, 2008). Currently tempe is known in many countries. Tempe was successfully passed as a new work item at the $\mathrm{CAC}$ at the 34th session of the Codex Alimentarius Commission (CAC) in Geneva July 9, 2011 (Republika Online, 2011). Indonesia has become the coordinator of the making of standard tempe in the Codex Alimentarius Commission and currently the draft standard has entered stage 5 in the Codex Year 2013 session.

Tempe is made of soybeans which are fermented using Rhizopus oligosporus mold(Figure 3). The mold that grows on soybeans produces enzymes that are able to change complex organic compounds into simpler compounds.. Foods fermentation usually have a higher nutritional value than the original ingredients. During tempe fermentation is produced new numerous compunds as result of degradation and synthesis process. Several of those compunds are considered as active compounds that are beneficial for health, example vitamin B12, isoflavones, and antibacterial (Astawan, 2018).

Besides amino acids and peptides, Rhizopus mold is able to transform isoflavone glycoside compounds into isoflavones aglycones during tempe fermentation (Purwoko et al. 2007). Tempe and miso contain the highest aglycone isoflavones compared to other soy fermentation derivatives because the molds of Rhizopus and Aspergillus can convert isoflavones glycosides to aglycones more strongly than other microbes (Coward et al. 1993). Aglycone isoflavones are known to have antioxidant activity. The antioxidant mechanism of aglycone isoflavones is preying on free radicals by phenolic groups. Glycoside isoflavone compounds are genistin, daidzin and glycitin, while the aglycone groups are called genistein, daidzein and glycitein (Friedman and Brandon, 2001). In tempe besides glycoside and aglycone groups there is also an antioxidant factor II (6,7,4 trihydroxy isoflavone) which has the most powerful antioxidant properties compared to isoflavones in soybeans (Astawan, 2009). Thus, tempeh is also useful as an antioxidant because it has compounds that have antioxidant activity.

The main problem with fresh tempe is its low durability due to its high moisture content (ie 5565 percent), as well as the presence of microbes. Therefore, a variety of tempe processing processes are needed to extend its durability and usefulness. Traditional processed tempe are fried tempe, tempe bacem, tempe mendoan, keripik tempe, sate tempe, botok tempe, sambal goreng tempe, and others. Tempe consumed in these forms is called first generation tempeh. The main characteristics of first generation tempeh products are their form and taste which are easily recognized by the general public (Astawan, 2008). The great efficacy of tempe, both in terms of nutrition and health, has encouraged the development of second generation and third generation tempe products. The second genarationtempe product can be in the form of tempe crackers, tempe balls, tempe burgers, sausage tempeh, tempe brownies, keik tempe, kukis tempe, tempe biscuits, soy sauce tempe, snack tempe, tempeh flour, tempe porridge, porridge tempe flour formula, milk tempeh, tempe ice cream, and other products that no longer have the typical shape and taste of tempe. 


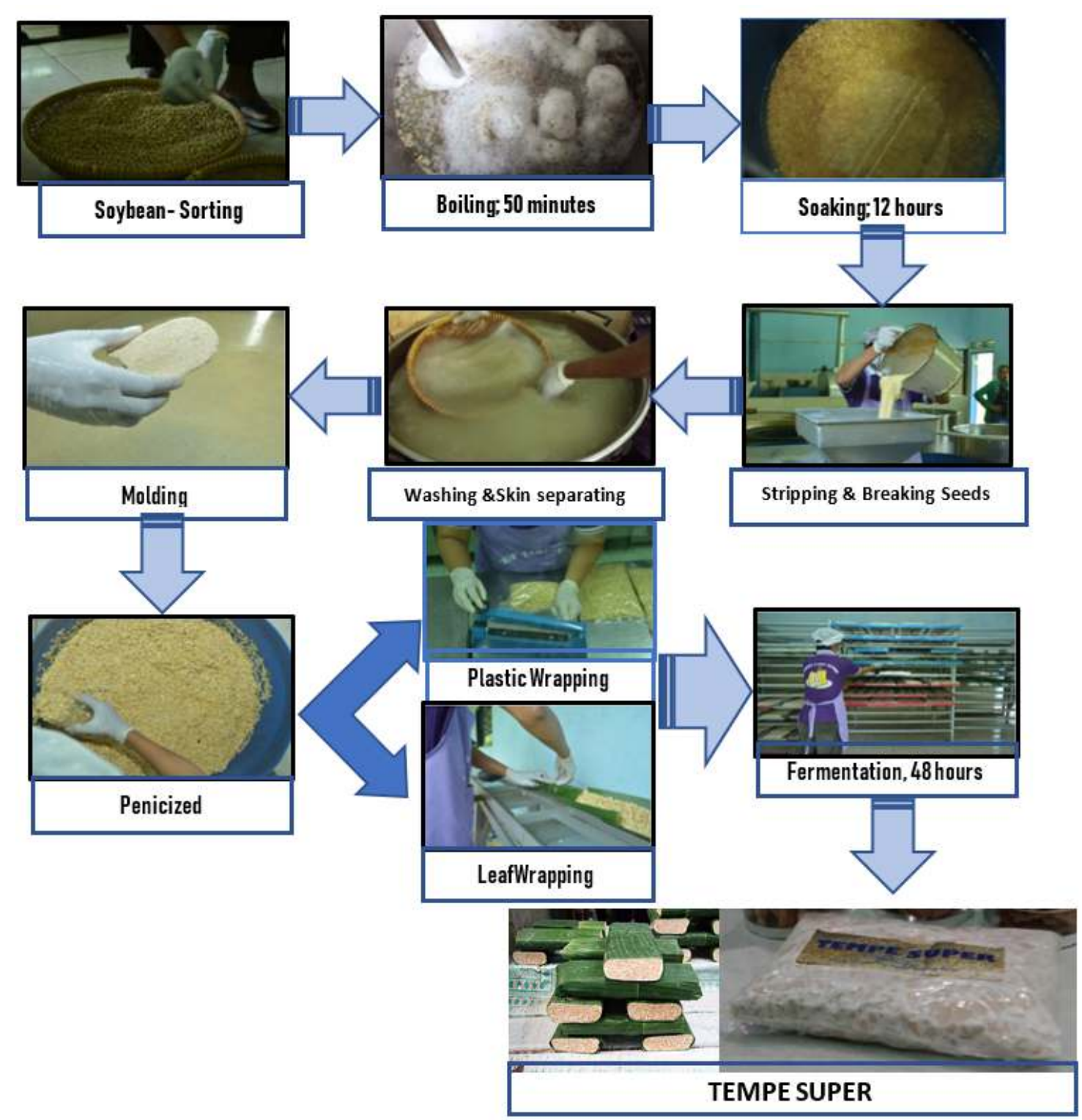

Figure 3. Tempe Processing

Through adequate knowledge that will be conveyed to partners about the benefits of tempe for the fulfillment of nutrition and health, it is expected that patners will be increasingly eager to increase production and market tempe products. The limited market for fresh tempeh which does not allow for increased production volume is expected to be overcome by the production of second generation processed tempe, such as tempe burgers, tempe nuggets etc. Considering that fresh tempe is easily decayed, then through the ability to produce various processed tempe products, the partners are expected not to worry about increasing the production of fresh tempe that is not absorbed by the market. Even if there is an excess of fresh tempe caused by an increase in tempe production, the producer partner does not need to worry because it can be processed into products that are more durable and value-added. 


\section{METHOD}

\section{Approach Method}

Based on the problems, the solutions offered to overcome the existing problems can be done using the following approaches:

a. The process of building resource motivation. This process is intended so that the resources to be empowered have a desire to advance business through increasing business capacity. The existence of active participation will have an impact on improving the welfare.

b. Increased business capacity. The process of increasing business capacity will have an impact on the welfare of tempe producers that have been cultivated for a long time but have not provided meaningful welfare. Increased business capacity is done by increasing production volume. Given the market limitations of fresh tempe, diversification of processed tempe products is carried out.

c. Mentoring process. To maintain commitment, the sustainability of the program and build good teamwork, the mentoring process will be carried out.

\section{Activity Plan}

To implement this empowerment method, the stages of empowerment activities are carried out with the following steps:

- The first stage, collecting data, facts and information relating to the problem of the object of community service.

- The second stage, compiling a joint plan through a focused discussion approach. In this process all stakeholders are involved. The purpose of this discussion is to get support and agree on a solution to the problem together.

- The third stage, compile a work plan. The results of focused discussions are included in the strategic plan matrix tables. The matrix will describe the objectives of the activity, location, scope, the role of the parties involved, planned costs needed, indicators of success and the post-mentoring sustainability process.

- The fourth stage, a technical implementation plan that contains a detailed time table in a large table. It is expected that all interested parties know the plan to be carried out. In this way all resources are involved in the management process which includes: planning, organizing, reporting and supervision.

- The fifth stage, the implementation of activities that have been planned and agreed with partners.

- The sixth stage, monitoring evaluation and preparing reports. At this stage the dissemination of the results of the implementation was also carried out, so that a comprehensive evaluation, discussion of sustainability and development efforts could be carried out. Dissemination is also intended to provide a learning process for other activities. All subsequent activities are published in the form of national-level scientific articles, so that indirectly they will also promote the efforts of partners.

\section{RESULT AND DISCUSSION}

\section{Preparation of Joint Plans through Focused Discussion Approaches.}

The purpose of this discussion is to get support on a solution to the problem together. In this discussion it was agreed to give the name of the tempe center and the specific brand of tempe and tofu produced. The name of the center is PUSAT TEMPE DAN TAHU SUPER (Center of Super Tempe and Tofu), while the product brand is agreed upon by TEMPE SUPER(Super Tempe) and TAHU SUPER (Super Tofu) (Figure 4).Super tofu will not be discussed further in this article. 


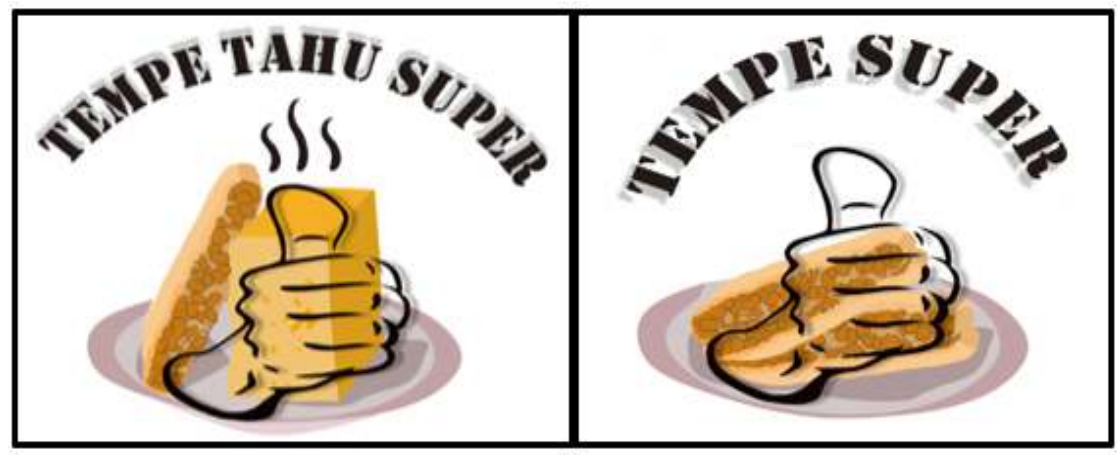

Figure 4. Logo of Tempe\& Tofu Center and Logo of Super Tempe

For marketing purposes were agreed to make hygienic tempe production videos, production uniforms, aprons and hats (Figure 5).
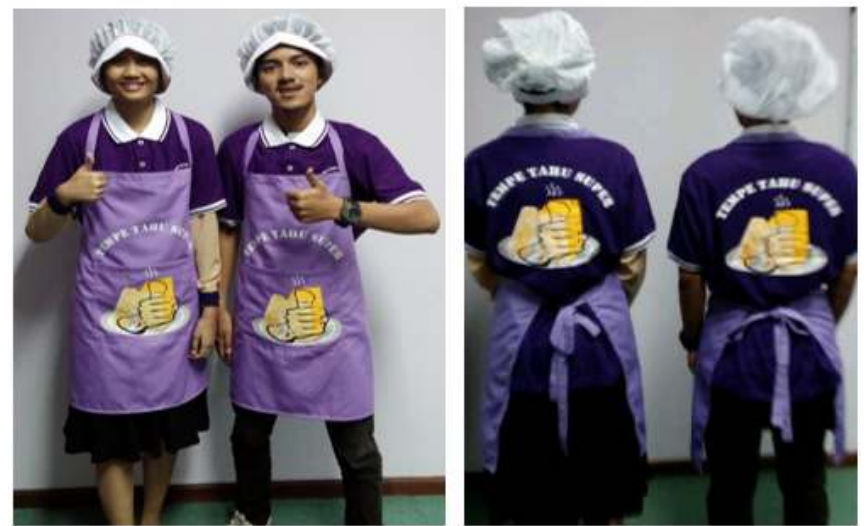

Figure 5. Uniform of Super Tempe and Tofu

\section{Training for Motivation of Business Development and Hygienic Tempe Production}

Business development can be done through a wider market penetration of fresh tempe products and diversification of tempe processed products. The motivation training was attended by 36 people. Participants in attendance were alltempeand tofu producers, and also several auxiliary workers (Figure 6).

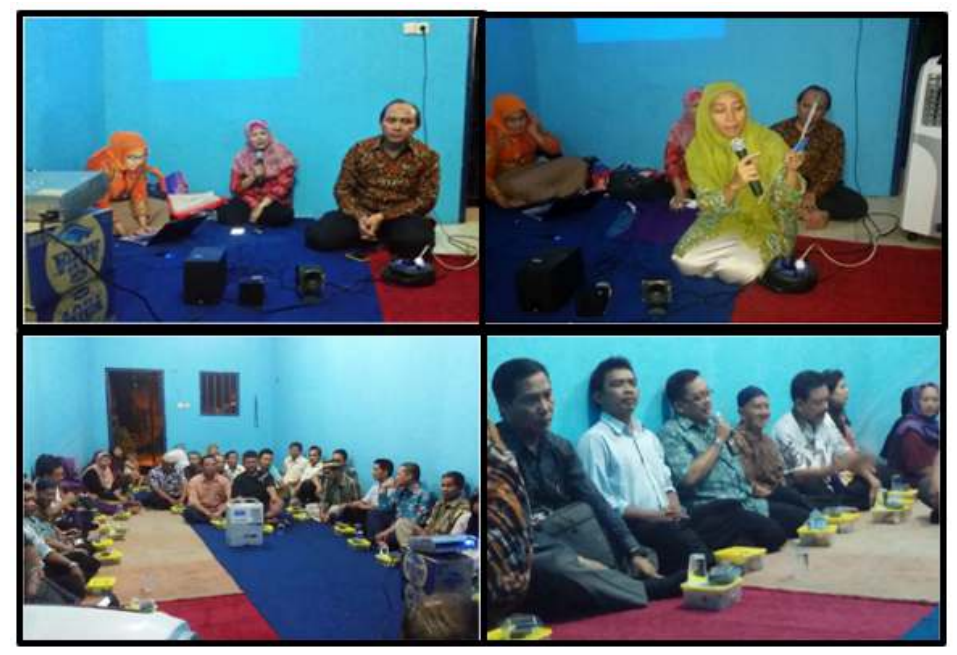

Figure 6. Training of motivational on business development and hygienic tempe production 
In addition to providing material to generate motivation for business development, on this occasion the participants were given knowledge about the benefits of tempe products. This knowledge is important so that the producers are more confident to develop a very useful food product business that not only provides nutritional benefits, but tempe is a functional food that is very good for health. So that the tempe producers in producing tempeh pay attention to hygiene and maintain food security. The producers are given training related to the Guidelines for Good Processed Food Production / CPPOB.To avoid using hazardous health ingredients into tempe and tofu produced, the Primkopti South Jakarta Management give warning for all producers. The ban is posted on the entrance wall of the processing room (Figure 7).
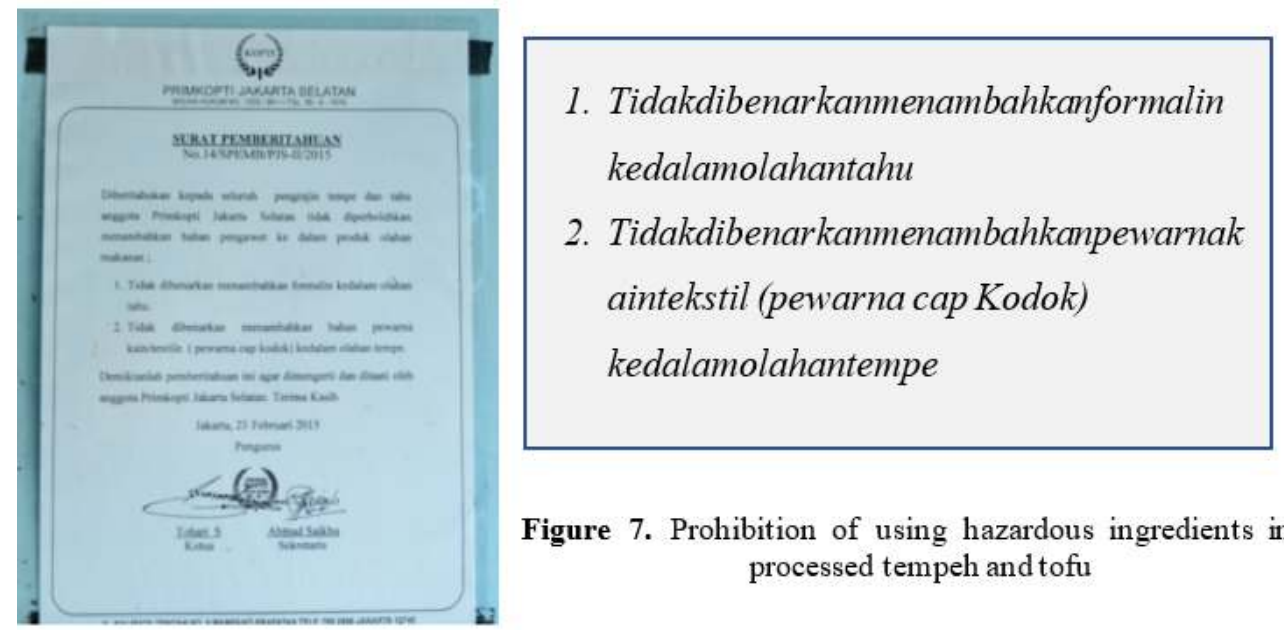

Figure 7. Prohibition of using hazardous ingredients in processed tempeh and tofu

\section{Training of Diversification of Tempe Processed Products}

To strengthen business development, new product development (product diversification) is needed. Products that want to be developed such as temperolades and tempenuget, which can be consumed as side dishes. Training / mentoring activities for processed tempeh processing technology are presented in Figure 8.The processing process of processed tempe products, temperolades and tempenuget, uses simple technology that can be done by small industries (Figure 9). However, the processing is carried out in a hygienic manner and environment. Food safety and comfort to consume these products is a top priority in production. Product photos of training are presented in Figure 10. Types of tempe processed products that are tested on this activity are the initial products. If this business is successful, it can be developed into a variety of products that are more varied. 


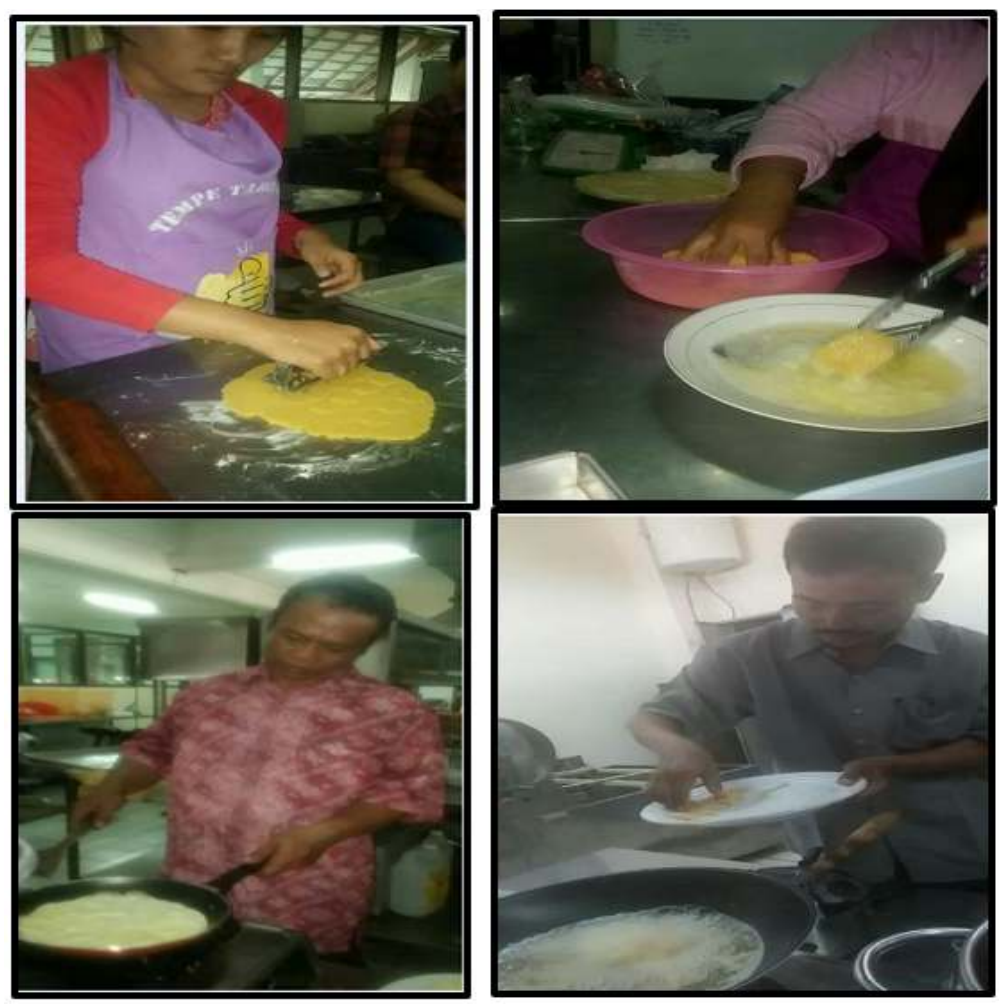

Figure 8. Appropriate technology training for the production of tempe processed products 


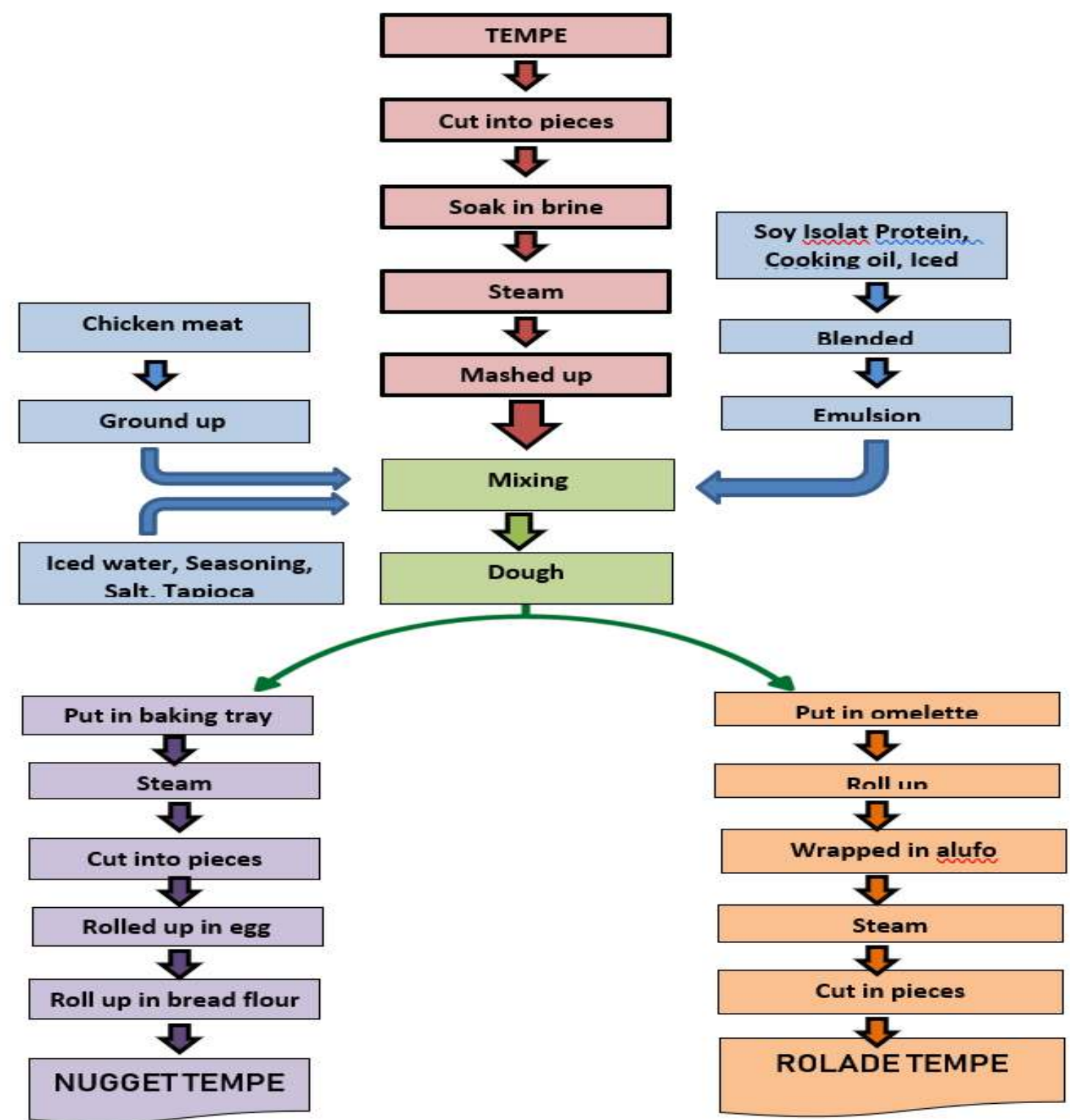

Figure 9. Processing of tempeh nuggets and rollades
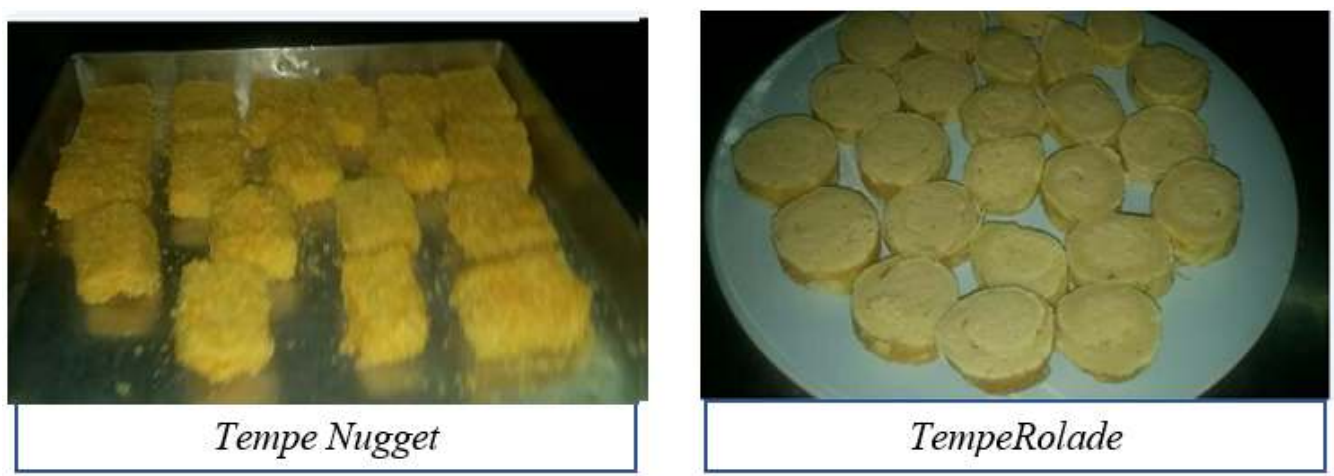

Figure 10. Processed tempe products during training 


\section{Assistance in Marketing of Tempe Processed Products}

In marketing activities, the types of processed products tested will be packaged and labeled attractive. Labels designed for production products and also the fresh tempeare presented in Figure 11 and Figure 12.

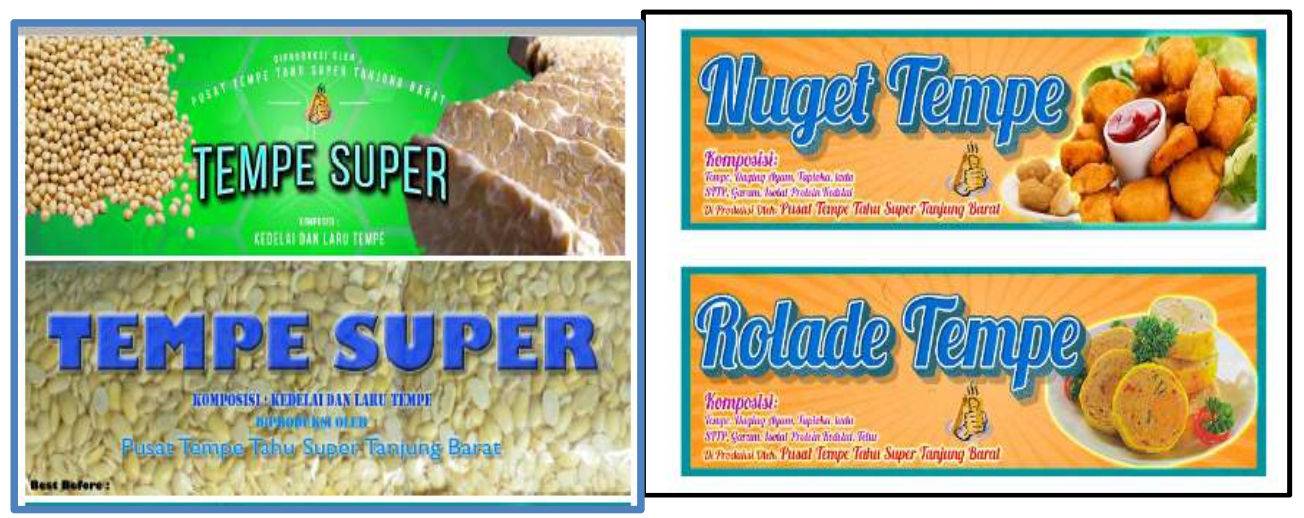

Figure 11. Label of Tempe nugget \& tempe rollade product and fresh tempe

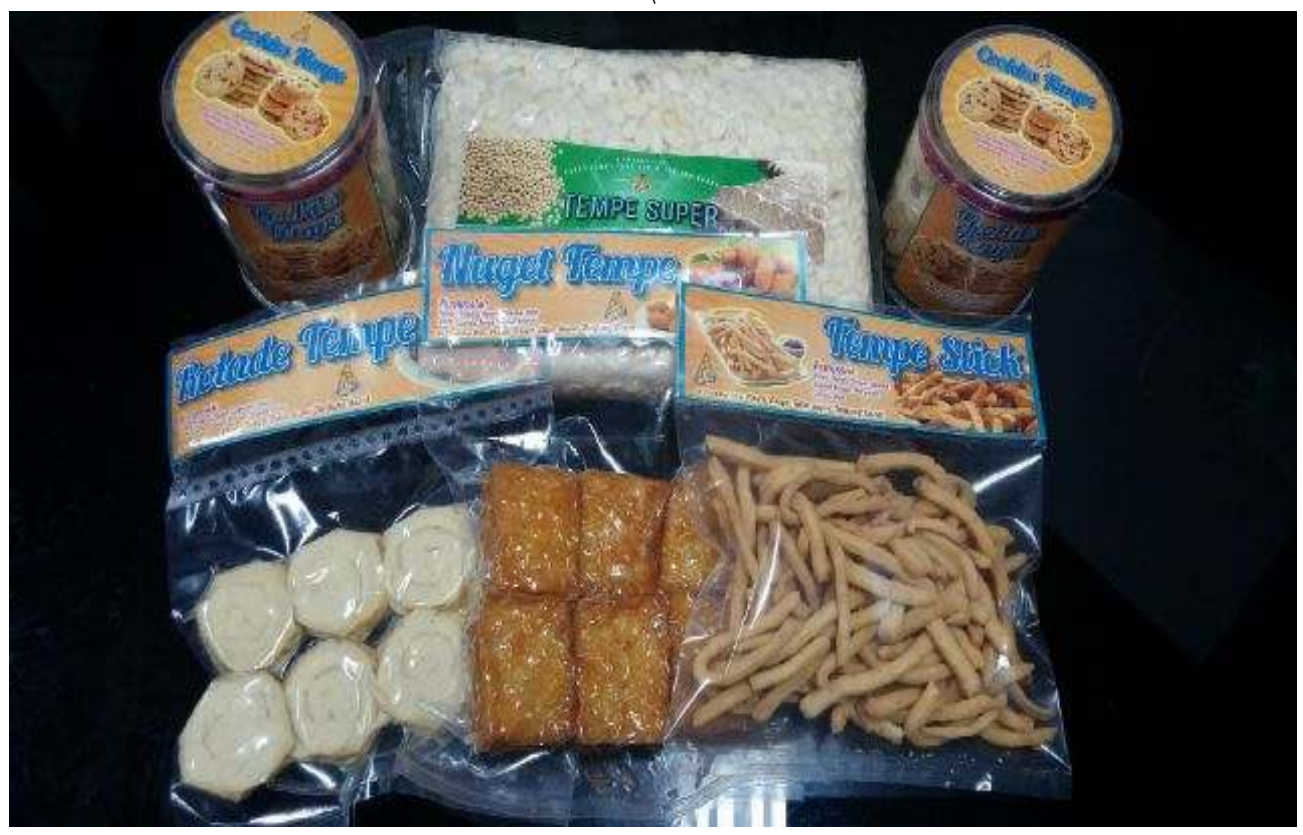

Figure 12. Packaged processed tempe products

To introduce Super Tempe, the team made a video and uploaded it on youtube. With these efforts, it is expected that Super Tempe in Lenteng Agung will be widely known by the community, so that production increases (Figure 13) 


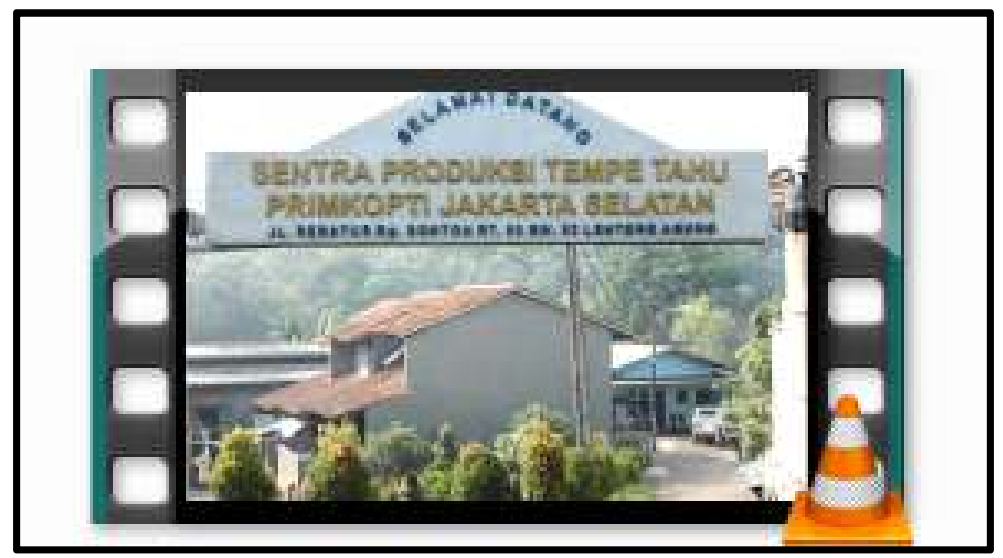

Figure 13. VideoWatch "PRODUKSI TEMPE SUPER LENTENG AGUNG" on YouTube https://youtu.be/oiahnxeA16I

\section{Training on Tempe Processed Product Business Development}

Training to find out the factors that influence business development is given specifically to Partners. On this occasion also taught how to calculate the feasibility of product development, including determining the final price of the product. The Partners also discussed the types of packaging that will be used to package the products produced, the market share to be addressed, and so on.

The price calculation for all processed tempe products is based on the cost of consumables such as raw materials, supplementary materials, supporting materials, packaging and labels. Labor costs are assumed to be $10 \%$ of the total cost of consumables, while for electricity, water and gas is assumed to be $5 \%$. For the selling price, the Partner is advised to take a profit of $15 \%-20 \%$ from the base price.

\section{CONCLUSION}

Problems faced by tempe producer partners to increase business capacity can be carried out through a strong desire to motivate themselves. The community development team acts as a facilitator for new product development (product diversification). This developed product will be a more durable and value-added product. The types of tempe processed products tested in this activity were the initial products, namely in the form of tempe nugget and roladetempe. If this business is successful, it can be developed into a variety of products that are more varied.

The processing process of processed tempe products uses simple technology that can be done by small industries. The processing is carried out in a hygienic way and environment. Food safety and comfort to consume these products is a top priority in production. To achieve the goal as a solution to these problems an approach has been carried out through training / mentoring of processed tempeh processing technology and adequate business management.To see the progress of business development, the partners need assistance in broader marketing. Tenacity is needed from the partners to continue to strive to develop a diversified product of tempe, so that the community becomes more familiar with tempe processed products.

\section{ACKNOWLEDGEMENT}

Acknowledgments were conveyed to the Directorate of Research and Community Development - Directorate General of Higher Education (DRPM - DIKTI) Ministry of Research and Higher Education which has financed this activity. 


\section{REFERENCES}

Astawan, M. (2008). Sehat dengan Tempe. Dian Rakyat, Jakarta.

Astawan, M. (2009). Sehat dengan hidangan kacang dan biji-bijian. Swadaya, Jakarta

Astawan, M. (2018). The Opportunities and Challenges of SMEs Tempe in Indonesia. USSEC - ITF International Tempe Seminar \& ITF Convention 2018. Bali, July 2018.

Codex Stan 313R. (2013). Regional Standard for Tempe. Codex Alimentarius.

Coward, L., Barnes, N. C., Setchell, K. D., \& Barnes, S. (1993). Genistein, daidzein, and their. beta.glycoside conjugates: antitumor isoflavones in soybean foods from American and Asian diets. Journal of Agricultural and Food Chemistry, 41(11), 1961-1967.

Friedmann, M., \& Brandon, D. L. (2001). Nutritional and healt benefits of soy protein. J. Agric. Food Chem, 49, 1069-1086.

Purwoko, T., \& Handajani, N. S. (2007). Kandungan Protein Kecap Manis Tanpa Fermentasi Moromi Hasil Fermentasi Rhizopus oryzae dan R. oligosporus. Biodiversitas, 8(2), 223-227.

Winarno, F. G. (1984). Kimia pangan dan gizi. PT Gramedia. 